\title{
China's Path to Sustainable, Stable and Rapid Economic Development: From the Largest to the Strongest Manufacturing Country
}

\author{
Yueyun (Bill) Chen \\ Department of Business Administration, University of the West, Los Angeles, USA
}

Email address:

Billchen@uwest.edu

To cite this article:

Yueyun (Bill) Chen. China's Path to Sustainable, Stable and Rapid Economic Development: From the Largest to the Strongest Manufacturing Country. Journal of World Economic Research. Special Issue: The Globalization and Economic Structure Changes.

Vol. 4, No. 5-1, 2015, pp. 8-19. doi: 10.11648/j.jwer.s.2015040501.12

\begin{abstract}
The global manufacturing trade comprises $70 \%$ of the total trade, and the manufacturing export from China comprises $93 \%$ of the country's total export. This paper explores the importance of continuously maintaining a strong manufacturing industry for China's future economic development. It emphasizes that in order to be a world economic leader, China must first have the strongest manufacturing industry; it then discusses the ways to achieve that objective.
\end{abstract}

Keywords: Economic Structure, Economic Growth, Globalization, China’s Economy

\section{Introduction}

China experienced rapid economic growth for more than two decades and became the second largest economy in the world in 2010. During the past several years, however, its economy has evidenced slower growth. In 2014, for example, its annual growth rate was only $7.4 \%$ and in 2013 that was $7.7 \%$, compared with the $9-12 \%$ annual growth rate in most previous years. This change in China's economy has caused world-wide concern since China is currently the major engine of global economic growth. It is estimated that China contributed about $30 \%$ of the world's economic growth in recent years. Therefore, whether China can sustain its rapid economic growth in the coming decades will affect not only the nation itself but also the entire world.

There are two scholarly perspectives about China's future. Pessimistic scholars believe that China will not be able to maintain the current level of growth in the future; they argue that China's economy will collapse in the near future in much the same way that some economies of developing countries experienced previously (Naughton (1995) and Lardy (1998)). Optimistic scholars, on the other hand, believe that China will be able to sustain its rapid economic growth for decades to come. Justin Lin $(2003,2012)$, former vice president of the World Bank and economist at Peking University, China, is a strong advocate among this group of optimistic scholars1.

To better forecast China's future, one needs to understand what factors contributed to China's past success and whether such factors will still be valid and feasible; in addition, one needs to look at new parameters that will emerge to stimulate China's future growth.

A country's economic growth stems from changes in domestic consumption, net exports and investments. China's past economic success was mainly due to its significant increases in exports and investments. As Graph 2 and Table 1 indicate, its total exports have been increasing over many years and its ratio of export to Gross Domestic Product (GDP) reached $36 \%$ in 2006; but that ratio decreased to about $25 \%$ in 2012 due to the slowing world economy2.

China became the number one country in attracting foreign direct investment (FDI) in 2007, surpassing the United States of America. FDIs have contributed significantly to China's economic development. They directly generate employment opportunities and increase outputs and productivities; in addition, FDIs directly help the country's exports. A

\footnotetext{
1 Lin believes that China will be able to maintain about $7-8 \%$ annual growth in the coming two decades. I believe that China can have $7.0-7.5 \%$ average annual growth from 2013 to 2022 and $6.0-7.0 \%$ from 2022 to 2031.

2 China had negative net export in $2013(-.4 \%)$ due to the slowing world economy.
} 
significant part of Chinese export is from these foreign direct investments. Although China is still an attractive place for FDIs, it will be difficult for China to continuously increase its ratio of investment to GDP from the current level.

China's total domestic consumption to the GDP ratio, on the other hand, has been stable at about $40 \%$ in most years in the past decades (Table 2)3. China's government recently has pushed very hard to stimulate its domestic consumption in order to counter-off the decreasing exports and so to maintain sufficiently high economic growth, but that effort has not been so effective.

From the above brief analyses, one can conclude that raising its domestic consumption is important for China's future economic development, but equally or even more important issues will be whether China can maintain its competitive advantages in export and in attracting FDIs.

This paper focuses on why China needs to continuously and further improve its manufacturing industry and how to achieve that objective.

\section{Review of Literature}

\subsection{Theories of Economic Growth}

The literature on economic growth is very rich. The classical growth theory (Ricardo (1817)) focuses the relationship between outputs and inputs of labor and capital, assuming no changes on the other conditions, including technology. The neoclassical theory (Solow (1956, 1957), Swan (1956)) attributes the technological change to growth and also emphasizes the importance of capital accumulations and increases. Their model and theory can also be used to explain how a developing country can catch up and maintain rapid economic growth through exogenous changes. The endogenous growth theory (Romer (1990), Lucas (1990)) focuses on the increases of human capital (like education) or technological change (like innovation) and its impacts on the economic growth rate. Energy and energy efficiency theories (Blumstein \& York (1980), Howarth (1993), Metcalf (1994)) emphasize the correlation between energy consumption and efficiency and economic growth. Institutional economics (growth theory) (Hamilton (1919), Coase (1937), Williamson (1975)), emphasizes the roles of political, legal and economic systems in a country's economic development.

\subsection{Studies on China's Fast Economic Growth}

There have been numerous studies on China's economy and particularly about its past rapid growth. The Beijing Consensus (Ramo (2004)) attributes China's economic success to its innovations in the state sector, including close financial controls, state ownership of firms, and political controls in favor of economic growth. These identified factors could explain China's early success in the late 1970s and 1980. The Washington Consensus (Huang 2010)) views

3 China's domestic consumption surpassed $50 \%$ of the total GDP in 2013 due to the negative net export.
China's success as the result from its financial liberation, private entrepreneurship and political opening. This view may better fit China's practices from the late 1990s.

Chow (2002) attributes China's rapid growth to its quality human capital, functioning market institutions and available technology from the world. Chow (2006) studies globalization and China's economic development and concludes the flows of goods, capital, technology/ information and people to and from China play the crucial roles. Tyers and Golley (2010) review the roles of demographic change and emphasize that China needs to reform its financial system in order to sustain its rapid growth in the future since it can no longer enjoy abundant and cheap labor.

Lin $(2003,2012)$ has done extensive studies on China's economy. He explored the sources for China's fast economic growth and whether that kind of growth will be sustainable in the coming decades. He stated that the government in a developing country like China needs to play an active role, not just through the traditional provision of infrastructure and legal enforcement, but also by identifying and actively supporting industries that contribute to growth. He further concluded that it is investment, not domestic consumption that has led to China's rapid economic development and that this will hold true for China's future success.

China's past economic miracle has been associated with its rapid urbanization. In 1978, its urbanization rate was only about $20 \%$; today it is above $50 \%$ (Graph $5 \&$ Table 8 ). As the world has experienced, a country's economic development will help improve its urbanization, and the urbanization itself in turn will contribute to its economic growth. As studies indicated, although China has been on a fast track of urbanization in the past decades, its current urbanization rate is still lower than the world's average and lower than the countries at the same income level (Chang (2002), Chang \& Brad (2006), Li (2001)).

\section{The Importance of Manufacturing Industry from Global Perspectives}

The manufacturing industry has been crucial to the world economy since the Industrial Revolution and will continue to be very important in the future. The manufacturing industry currently still shares $16 \%$ of global GDP, $70 \%$ of global trade, $14 \%$ of global employment, and $77 \%$ of private sector R\&D (McKinsey (2012)).

McKinsey Global Institute classified the manufacturing industry into five types of groups: labor-intensive, energy/resource-intensive, regional processing, global innovations for local markets, and global technologies/ innovations. Advanced/developed economies had \$342 billion worth of trade deficits in labor-intensive goods but had a \$726-billion trade surplus in innovative goods. In other words, Western countries, in fact, had a net trade surplus of $\$ 376$ billion in these two manufacturing groups. Among these five groups, China leads in the first three and the US 
leads in the later 2 groups (Graph $2.2 \&$ Table 3).

There are also service jobs in the manufacturing industry. Every dollar of manufacturing output needs about $\$ 0.19$ of service input. Service type activities make up $30-55 \%$ of manufacturing employment (McKinsey (2012)).

The manufacturing industry is still important to developed economies as well as developing ones. Manufacturing constitutes about $30 \%$ of Germany's GDP; in the US the figure is about $20 \%$, and in China it is about $40 \%$. It has been a common pattern that when a country becomes wealthier, the manufacturing share of its GDP and the employment in its manufacturing sectors will gradually decrease. The US employment in manufacturing declined from $25 \%$ in 1950 to about $10 \%$ in 2008; in Germany jobs in manufacturing fell from $35 \%$ in 1970 to about $20 \%$ in 2008; in South Korea the figures went from $28 \%$ in 1989 to $17 \%$ in 2008 . But as indicated above, such significant decreases of the percentage of employment in the manufacturing industry will be realized over decades, not in several years. In other words, each year's decrease will be much less significant.

US companies outsourced many manufacturing plants to other countries, including China and other places in eastern Asian. Recently, the US government has tried to insource these companies again and make products here by providing special financial and other support since the US has recognized the importance to employment and the economy of manufacturing more home-made products. It is very difficult to reverse that trend generally although a few companies have managed to shift some of their manufacturing facilities back to the US. If a country allows its manufacturing to be outsourced, it will be not easy to get it back later.

China must be very careful and not allow its manufacturing sector to shrink too fast since this sector has been the main source of China's past success and will still be crucial to its future growth.

\section{The Importance of Manufacturing Industry to China-Past, Present and Future}

The rapid development of its manufacturing industry contributed the most to China's past economic success. China has become a global manufacturing center. In 2000, China exported $\$ 219.3$ billion worth of manufacturing products, and in 2011 , the figure was $\$ 1,768.5$ billion (Table 5). In 1990, China ranked number 7 in the world in terms of gross manufacturing values added, it was number 4 in 2010, and now ranks virtually the same as the US at number 1 in the world (World Economic Forum (2012)).

As Table 5 shows, from 2000 to 2011, China's total export increased 6.62 times and its manufacturing export increased 7.06 times. In 2000, manufacturing export made up $88 \%$ of China's total export and in 2011, it constituted 93\%, accordingly.

China has about 1.4 billion people. Solving its employment problem will be a continuous and significant challenge to China. Each year, China has more than 7 million college graduates. In addition, millions of farmers move to the cities/towns each year through urbanization. In order to create millions of new jobs and solve its employment problems, China must maintain fast economic growth in the coming decades. It is estimated that an annual $1 \%$ economic growth will generate about 1.5 million new jobs. Therefore, a minimum $7-7.5 \%$ annual growth will be necessary to add about 10-12 million new jobs each year.

In the past two decades, China has increased its urbanization rate by about $1 \%$ annually, and currently about $55 \%$ of the population live/work in urban areas. The urbanization rate in China will continue to rise in the coming two decades, until it reaches about $70-75 \%$.

Providing jobs to both college graduates and farmers moving to the cities is the most important factor in China's economic development and social stability. The manufacturing industry will still represent a major source of these job opportunities. Currently about $30 \%$ of China's jobs are in the industrial sectors.

Attracting FDIs is equally important to China's future development. About $45 \%$ of these FDIs go directly to the manufacturing sectors. Therefore, continuously developing the manufacturing industry will help China better attract FDIs in the future as well as solve its employment problems and increase its outputs and exports.

Developing and strengthening its manufacturing industry can also help China reduce the import of manufacturing products. Although China has a huge trade surplus, it still imports many manufacturing goods. China imports $2 / 3$ of its fixed asset investments from other countries, including $100 \%$ of fiber-making machines, $85 \%$ of chip-making machines, $80 \%$ of petroleum machines, and $70 \%$ of machine tools. By developing an advanced manufacturing industry, China will be able to significantly reduce these imports.

The productivity of China's manufacturing industry is very low. China's manufacturing share of the world is about $20 \%$, virtually the same as the US, but China employs 100 million people while the US manufacturing workforce numbers only 11.5 million. China's manufacturing productivity is only about $1 / 6-1 / 8$, compared with that of Western countries. Total sales of the largest four steel companies in China are only about $65 \%$ of the sales of one Japanese steel company. Further developing and improving its manufacturing industry will help China improve its productivity and thus its competitiveness.

\section{How Can China Become a Manufacturing Leader}

In order to be a manufacturing leader, a country needs to develop and maintain competitiveness and advantages in education, innovation, labor, technology, capital, and management.

China produces more than 7 million college graduates each 
year as well as thousands of graduates with master's and doctoral degrees. Investing in science and education has become China's national development strategy for decades, and this has produced significant results. China's total spending on R \& D surpassed 2\% of its GDP in 2012 (Graph 3 ). In 2013, for the first time, China's education spending reached $4 \%$ of its annual GDP as Premier Wen announced during his annual press conference in 2013. China's total registered patents have been ranked number 1 in the world, surpassing the US although its utilization rate of these patents is relevantly low, compared with Western countries. China has established strong educational and technological conditions to lead its manufacturing industry.

China still has ample labor resources to support the manufacturing industry although such labor cost has been increasing significantly over the past few years. China needs to improve its management and particularly reform its economy and policies so that all manufacturing companies can compete fairly and fully. The market will then decide the winners and losers, not the government or its officials.

To become a manufacturing leader, China needs to focus on the following particularly:

\subsection{Innovations and Intellectual Property Rights}

Innovation is the most important factor in the development of advanced technologies. On the one hand, China has been extremely successful in developing high tech in aerospace and other related industries. On the other hand, China still lacks innovations in many industries and products, in general. As a result, China needs to import huge amounts of advanced equipment and technologies, as mentioned, and it lacks globally recognized brands and products.

In order to be a global manufacturing leader, China needs to invest more and encourage more innovation. Protection of intellectual property rights is the key to innovations; otherwise, companies and individuals will not be motivated to innovate. Also, to continuously attract FDIs, China must fully implement its laws/regulations to protect these intellectual property rights.

\subsection{A National Manufacturing Industry Strategy and Plan}

China needs to have a national manufacturing development strategy and plan. First, it needs to emphasize the importance of maintaining a strong manufacturing industry. Second, it needs to set up long-term objectives and goals for its manufacturing industry with regard to world market shares in different manufacturing groups/sectors, improvement of high-level/advanced manufacturing sectors, and domestic allocations of the manufacturing industry in different regions/provinces. In addition, China needs to develop and implement relevant policies and provide necessary financial supports to achieve such a strategy and plan.

China is a huge country, and each region is in a different stage of development. Coastal cities/regions are well developed and the cost of doing business there is high. As a result, traditional manufacturing companies have left or are leaving these regions. Many of them have gone to other countries, including Vietnam and Malaysia. Some have moved to less developed areas like the western region of China. In order to keep more manufacturing companies at home, China needs to evaluate its business conditions and develop a relevant strategy and plan; particularly it needs to evaluate and identify what types of companies are suited to moving to other regions and how to assist that relocation. China should take advantage of its regional differences to host different levels of manufacturing sectors. China's unique socialism-market system should play an important role in such a plan.

It is very important to remember that even in an advanced economy like the US, Germany or Japan, the low skill/technology intensive and labor intensive/resource-based sector is still significant and important (18\% in Germany, $14 \%$ in the US and $17 \%$ in Japan) (Table 5). China has a high percentage $(39 \%)$ of this low-level manufacturing sector, and this number needs to change. But such a change should result mainly from adding higher-level manufacturing sectors, not from dramatically shrinking this low-level sector.

This kind of strategy should also include how to develop and produce new products to substitute or reduce the current huge manufacturing imports as well as how to sustain the appropriate percentage of manufacturing export to total export in the future.

\subsection{Product/Company Brands and Reputations}

Having its own brands and a good reputation is very important to a company's success. Increasingly, China has companies joining the club of the world's largest companies. But only a few of these mega companies are manufacturing companies. Although China is the world's manufacturing center and exports huge amounts of products, the majority of these products are sold overseas under the importers' own brands. The only label on these products is "Made in China". Japan and South Korea's manufacturers are more successful because they have their own global brands such as Toyota cars and Samsung TVs and phones. China will not be a manufacturing leader if it does not develop many leading manufacturers with their own globally recognized brands.

\subsection{Quality}

High quality is essential for establishing brands and good reputations. Quality also is an important factor for shaping a company's competitiveness. During the recent economic crisis, the world's total demand for manufacturing products, including machine tools and other equipment, has been much lower, and so many manufacturers have suffered; but Germany's manufacturing industry has not been very negatively affected because of its high quality and strong competitiveness.

Japan-made products used to have a low-quality image in the 1970s and early 1980s; but Japanese industry made significant efforts and as a result now products made in Japan 
are the very symbol of good quality.

The popularity of China-made products suffered in US supermarkets in recent years because of quality issues and poor image (Chen (2011)). Similar products made in China will be much cheaper in the US, than ones made in Japan, the US or Germany. Some Western companies have moved out from China and relocated to their home countries, like the US or Japan, because of the reasons mentioned above.

To be an industry leader, a company must produce quality products. To become the strongest manufacturing country, it must provide high quality products.

\subsection{Productivity}

As pointed out in the previous section, the productivity level in China's manufacturing industry is relevantly low. In order to be a global manufacturing leader, China must invest more and develop and implement policies to significantly improve its productivity.

Also, given the fact that the increasing contributions from foreign investments and exports to its future economic growth will be more difficult, China has no choice but must significantly improve its productivity in order to sustain the possible rapid economic growth (Mark Purdy (2013), Graph 4).

To improve productivity, Chinese companies need to adopt new technologies, use more effective production processes, better train and use employees, improve management and quality, reduce waste and defectives, and control inputs, inventories and other expenses.

\subsection{Economies of Scale}

Another way to improve productivity is to better use the economies of scale. Most manufacturing products have significant economies of scale, i.e. the more outputs and larger scale the company has, the lower the average cost will be. As a result, larger companies will have lower cost and thus earn the competitive advantage. As mentioned in the previous section, many Chinese manufacturing companies are too small, compared with those of Western countries. For example, China is the world's largest steel user, but the total sales of its four largest steel companies are equal to only about $65 \%$ of the sales of one Japanese steel company.

Mergers and acquisitions are ways to change the market structure of an industry and particularly to form big ones. It should be free market competition that eliminates bad companies and allows good ones to grow and acquire others. Private companies, not necessarily state-owned-enterprises (SOEs) can be the winners in such mergers and acquisitions.

\subsection{Energy Efficiency}

Energy efficiency is crucial for a company and a country's sustainable development. Given limited resources, one must conserve energy and other resources. Energy efficiency will also help a company lower its cost and improve its competiveness. Improving energy efficiency in the manufacturing industry will help innovate its production processes and technology, thereby modernizing facilities and productions. This will in turn also help reduce pollution and solve other environmental problems.

\subsection{Comprehensive Globalization}

Globalization has been an irreversible world trend because of the agreements under the World Trade Organization (WTO), fast developments and adoptions of information technologies, faster transportation systems; multinational corporations (MNCs) and their developments; and mass immigrations. As a result, global economies and financial and other markets are increasingly integrated and interdependent.

Globalization means to use both domestic and international resources; target both domestic and international markets; and face both domestic and international business environments (both domestic and international regulations, legal systems, political systems, cultures, languages, and others).

China benefited in the past from globalization and from its openness to the world. But in order to be a world economic leader, China needs to pursue comprehensive globalization, instead of simple and pure market-oriented globalization. Most Chinese companies currently make their products in China and then sell them all over the world. This is a kind of market-globalization.

Comprehensive globalization should also include: (1) production and distribution globalization-making parts in different countries/locations and assembling all together in another place as in the case of Apple phones; (2) resources globalization-particularly owning/directly-using natural resources in other countries; (3) human resources globalization-especially attracting talent from all over the world; (4) financial globalization-financing in the world and its currency accepted globally; (5) institutional globalization - reforms and changes of regulations/laws to be consistent with global standards/practices; (6) cultural globalization - establishing and using the soft-power with its culture, and (7) language globalization-making one's language more widely used and adopted.

China's current globalization level is very low and has large potential to be improved. In particular, many Chinese companies often open and occupy other markets through cheap prices, which has caused serious trade disputes. Japanese companies faced similar problems in the 1980s and early 1990s, but they solved or eased these problems by allocating factories to target countries through production and distribution globalization.

Financial globalization is also very important to China's future development. Chinese companies are now experiencing less benefit and competitive advantage from abundant and cheap labor. Financial reforms and financial globalization will help China and Chinese companies generate new competitive advantage through more efficient allocations of capital, equal access of the capital by private companies, and lower financing and transactions costs. 


\section{Conclusions}

This paper focuses on how to improve China's manufacturing industry to help solve its economic problems-employment, growth, export, and competitiveness. It emphasizes that this industry will remain the key to China's future rapid economic growth and success.

In the past several years, we have observed that China's growth slowed down and its unemployment rate rose. At the same time, we saw that some foreign manufacturing companies relocated from China to other countries while many traditional manufacturers in coastal cities were forced to move out or completely close. Thus, many questions arise. What will be China's future? Can China sustain its rapid economic growth in the coming decades? If so, how to achieve that? Is the manufacturing industry still relevant and important to China's future? If so, how can this industry improve?

In order to sustain its rapid economic growth in the coming two decades, China needs to solve the economic and social problems that it faces and will face, significantly raise its domestic consumption, better develop its service industry, continuously attract foreign direct investments, and further reform its economic and financial systems. Furthermore,
China needs to become the strongest manufacturing country in order to maintain a rapid, sustainable and stable economic growth. To achieve this, China needs to be more innovative and offer better protection of intellectual property rights; develop and implement a national manufacturing strategy and plan; establish more globally recognized brands and robust reputations; improve its product quality; significantly improve its productivity; benefit more from economies of scale; become more energy efficient; and adopt more comprehensive globalization.

China will have a better and bright future since its people and leaders know that continuously developing the economy and improving people's lives are of utmost importance. They will be successful in the future because they have learned and will continue to learn from their mistakes and because they are willing to make the changes and reforms necessary to correct these mistakes.

Hundreds of years ago, China dominated the world economy. In the near future, a rapidly rising China will again be a strong leader in the world economy. That not only is the dream of many Chinese people, but also will become their reality, if China can take the right path and is able to solve its social and economic problems.

\section{Appendixes and Data Sources}

Unless otherwise mentioned, all data sources of the graphs/tables in the Appendixes are from "China Statistics," National Bureau of Statistics, China, various years.

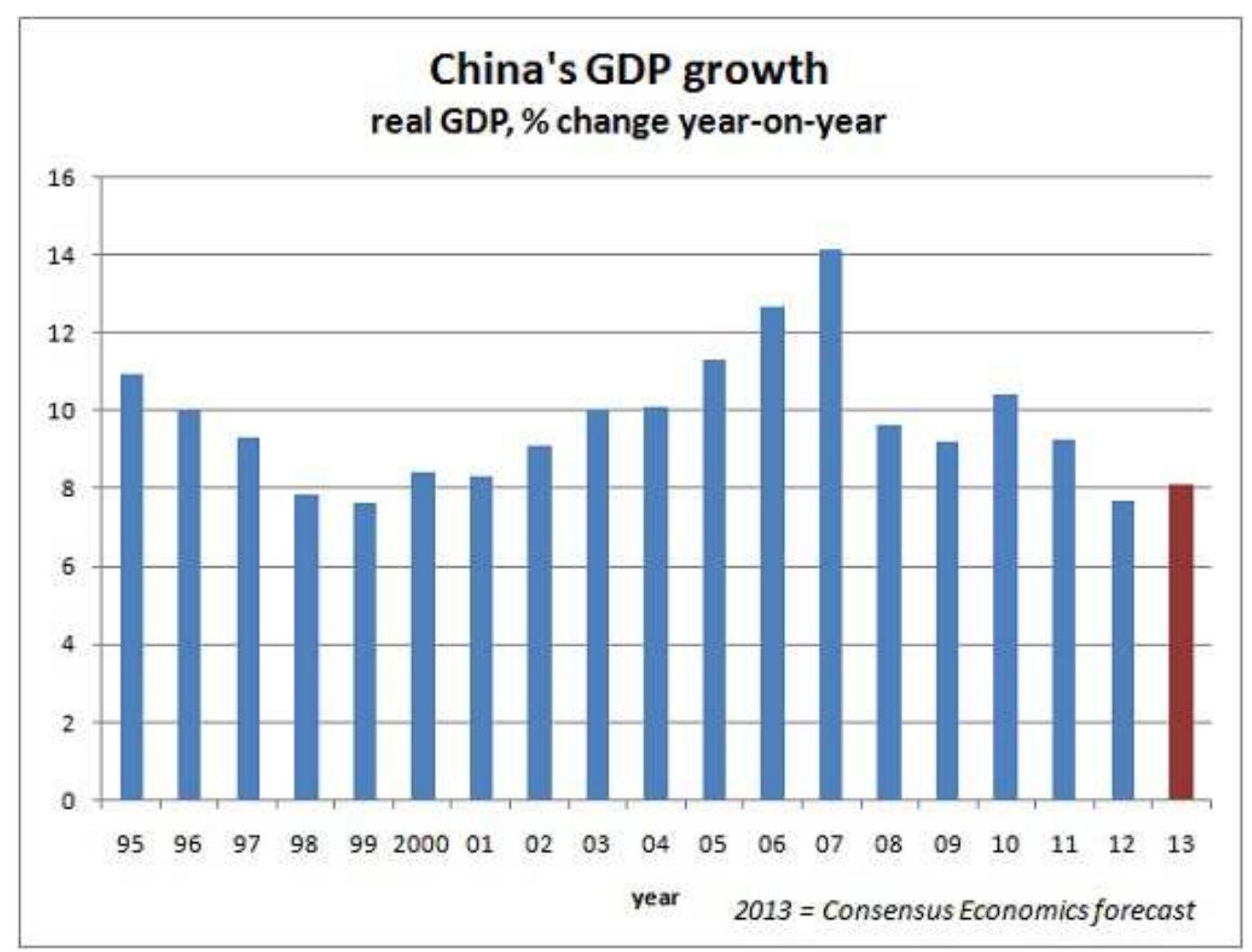

Graph 1. China's Annual Growth Rate (1995-2013). 


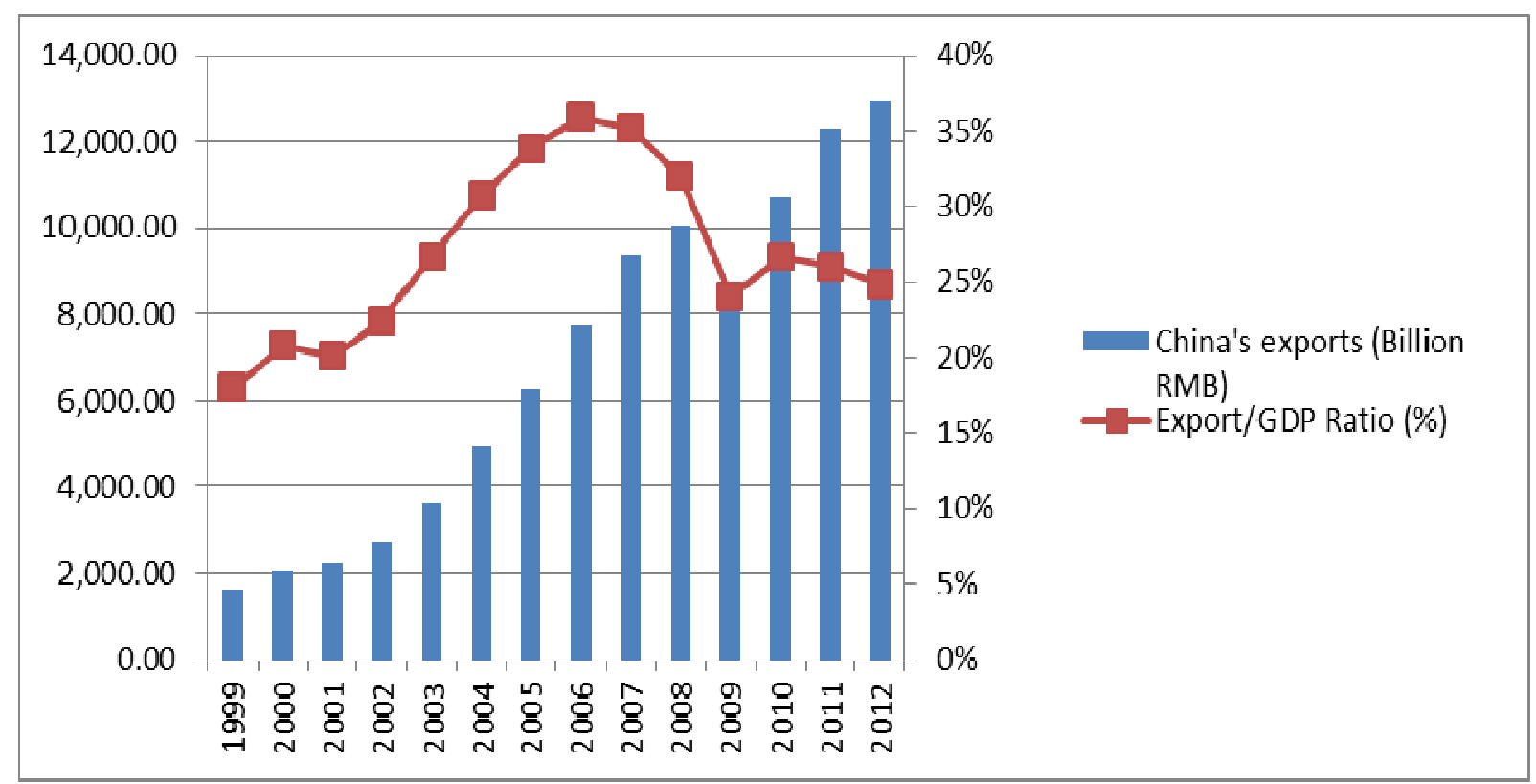

Graph 2. China's Total Export and Export/GDP Ratio (1999-2012).

Table 1. China's Total Export and Export/GDP Ratio (1999-2012).

\begin{tabular}{|c|c|c|c|c|c|c|c|c|c|c|c|c|c|c|}
\hline & 1999 & 2000 & 2001 & 2002 & 2003 & 2004 & 2005 & 2006 & 2007 & 2008 & 2009 & 2010 & 2011 & 2012 \\
\hline $\begin{array}{l}\text { China's } \\
\text { exports } \\
\text { (Billion } \\
\text { RMB) } \\
\text { China's }\end{array}$ & $\begin{array}{l}1,615 . \\
98\end{array}$ & $\begin{array}{l}2,063 . \\
44\end{array}$ & $\begin{array}{l}2,202 \\
44\end{array}$ & $\begin{array}{l}2,694 . \\
79\end{array}$ & $\begin{array}{l}3,628 . \\
79\end{array}$ & $\begin{array}{l}4,910 . \\
33\end{array}$ & $\begin{array}{l}6,264 . \\
81\end{array}$ & $\begin{array}{l}7,759 . \\
72\end{array}$ & $\begin{array}{l}9,356 . \\
36\end{array}$ & $\begin{array}{l}10,039 \\
.49\end{array}$ & $\begin{array}{l}8,202 . \\
97\end{array}$ & $\begin{array}{l}10,702 \\
.28\end{array}$ & $\begin{array}{l}12,324 \\
.06\end{array}$ & $\begin{array}{l}12,935 \\
.93\end{array}$ \\
\hline $\begin{array}{l}\text { GDP } \\
\text { (Billion } \\
\text { RMB) }\end{array}$ & $\begin{array}{l}8,967 . \\
71\end{array}$ & $\begin{array}{l}9,921 . \\
46\end{array}$ & $\begin{array}{l}10,965 \\
.52\end{array}$ & $\begin{array}{l}12,033 \\
.27\end{array}$ & $\begin{array}{l}13,582 \\
.28\end{array}$ & $\begin{array}{l}15,987 \\
.83\end{array}$ & $\begin{array}{l}18,493 \\
.74\end{array}$ & $\begin{array}{l}21,631 \\
.44\end{array}$ & $\begin{array}{l}26,581 \\
.03\end{array}$ & $\begin{array}{l}31,404 \\
.54\end{array}$ & $\begin{array}{l}34,090 \\
.28\end{array}$ & $\begin{array}{l}40,151 \\
.28\end{array}$ & $\begin{array}{l}47,310 \\
.41\end{array}$ & $\begin{array}{l}51,947 \\
.01\end{array}$ \\
\hline $\begin{array}{l}\text { Export/ } \\
\text { GDP }\end{array}$ & 0.1802 & $\begin{array}{l}0.207 \\
977\end{array}$ & $\begin{array}{l}0.2008 \\
51\end{array}$ & $\begin{array}{l}0.2239 \\
45\end{array}$ & $\begin{array}{l}0.2671 \\
71\end{array}$ & $\begin{array}{l}0.3071 \\
29\end{array}$ & $\begin{array}{l}0.3387 \\
53\end{array}$ & $\begin{array}{l}0.3587 \\
24\end{array}$ & $\begin{array}{l}0.3519 \\
94\end{array}$ & $\begin{array}{l}0.3196 \\
83\end{array}$ & $\begin{array}{l}0.2406 \\
25\end{array}$ & $\begin{array}{l}0.2665 \\
49\end{array}$ & $\begin{array}{l}0.2604 \\
94\end{array}$ & $\begin{array}{l}0.2490 \\
22\end{array}$ \\
\hline
\end{tabular}

Table 2. China's Total Consumption, Export and Investment (1990-2012).

\begin{tabular}{|c|c|c|c|c|c|c|c|}
\hline Year & $\begin{array}{l}\text { Total GDP } \\
\text { (100 Million } \\
\text { RMB) } \\
\end{array}$ & $\begin{array}{l}\text { Total Consumption } \\
\text { (100 Million RMB) }\end{array}$ & $\begin{array}{l}\text { \% of } \\
\text { Consumption/G } \\
\text { DP }\end{array}$ & $\begin{array}{l}\text { Total Net- } \\
\text { Export (100 } \\
\text { Million RMB) } \\
\end{array}$ & $\begin{array}{l}\% \text { of Net- } \\
\text { Export/GD } \\
P\end{array}$ & $\begin{array}{l}\text { Total Domestic } \\
\text { Investment (100 } \\
\text { Million RMB) }\end{array}$ & $\begin{array}{l}\% \text { of } \\
\text { Investment/GD } \\
P\end{array}$ \\
\hline 1990 & 18667.8 & 8300.1 & 0.44 & 2985.8 & 0.16 & 7381.9 & 0.40 \\
\hline 1991 & 21781.5 & 9415.6 & 0.43 & 3827.1 & 0.18 & 8538.8 & 0.39 \\
\hline 1992 & 26923.5 & 10993.7 & 0.41 & 4676.3 & 0.17 & 11253.5 & 0.42 \\
\hline 1993 & 35333.9 & 14270.4 & 0.40 & 5284.8 & 0.15 & 15778.7 & 0.45 \\
\hline 1994 & 48197.9 & 18622.9 & 0.39 & 10421.8 & 0.22 & 19153.2 & 0.40 \\
\hline 1995 & 60793.8 & 23613.8 & 0.39 & 12451.8 & 0.20 & 24728.2 & 0.41 \\
\hline 1996 & 71176.6 & 28360.2 & 0.40 & 12576.4 & 0.18 & 30240.0 & 0.42 \\
\hline 1997 & 78973.0 & 31252.9 & 0.40 & 15160.7 & 0.19 & 32559.4 & 0.41 \\
\hline 1998 & 84402.3 & 33378.1 & 0.40 & 15223.6 & 0.18 & 35800.6 & 0.42 \\
\hline 1999 & 89677.1 & 35647.9 & 0.40 & 16160.0 & 0.18 & 37869.2 & 0.42 \\
\hline 2000 & 99214.6 & 39105.7 & 0.39 & 20634.4 & 0.21 & 39474.5 & 0.40 \\
\hline 2001 & 109655.2 & 43055.4 & 0.39 & 22024.4 & 0.20 & 44575.4 & 0.41 \\
\hline 2002 & 120332.7 & 48135.9 & 0.40 & 26948.0 & 0.22 & 45248.8 & 0.38 \\
\hline 2003 & 135822.8 & 52516.3 & 0.39 & 36288.0 & 0.27 & 47018.5 & 0.35 \\
\hline 2004 & 159878.3 & 59501.0 & 0.37 & 49103.3 & 0.31 & 51274.0 & 0.32 \\
\hline 2005 & 184937.4 & 68352.6 & 0.37 & 62648.1 & 0.34 & 53936.7 & 0.29 \\
\hline 2006 & 216314.4 & 79145.2 & 0.37 & 77597.2 & 0.36 & 59572.0 & 0.28 \\
\hline 2007 & 265810.3 & 93571.6 & 0.35 & 93563.6 & 0.35 & 78675.1 & 0.30 \\
\hline 2008 & 314045.4 & 114830.1 & 0.37 & 100395.0 & 0.32 & 98820.3 & 0.31 \\
\hline 2009 & 340902.8 & 132678.4 & 0.39 & 82029.7 & 0.24 & 126194.7 & 0.37 \\
\hline 2010 & 401512.8 & 156998.4 & 0.39 & 107022.8 & 0.27 & 137491.6 & 0.34 \\
\hline 2011 & 473104.1 & 183918.6 & 0.39 & 123240.6 & 0.26 & 165944.9 & 0.35 \\
\hline 2012 & 519470.1 & 210307.0 & 0.40 & 129359.3 & 0.25 & 179803.8 & 0.35 \\
\hline
\end{tabular}




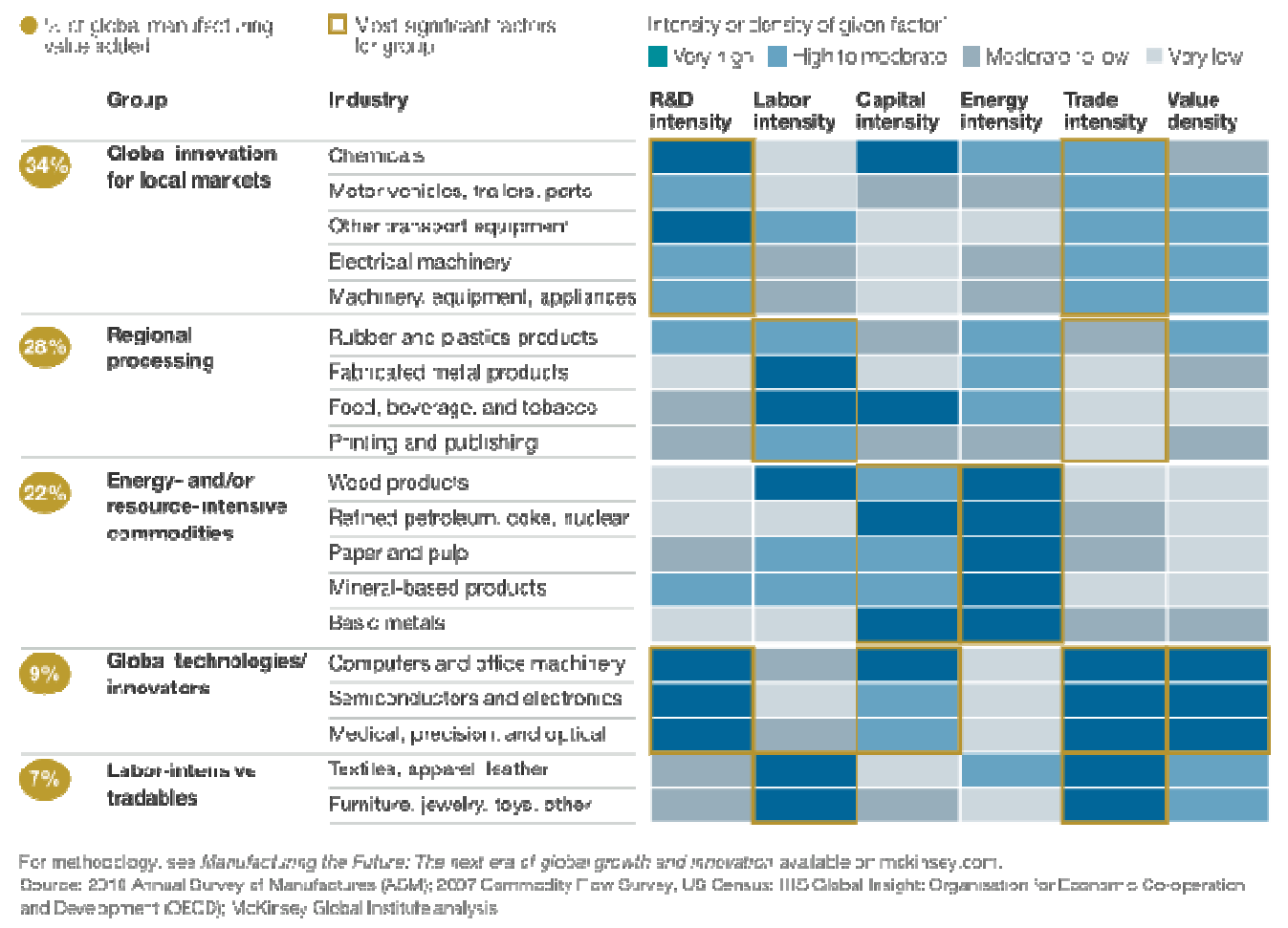

Graph 2.2. Different Groups of Manufacturing and its Characteristics.

Table 3. 2000 \& 2011 Manufacturing Export Competitiveness (\$ billion).

\begin{tabular}{llll}
\hline & $\mathbf{2 0 0 0}$ & $\mathbf{2 0 1 1}$ & \% change \\
\hline China & 219.3 & $1,768.5$ & 7.06 \\
Germany & 459.2 & $1,226.3$ & 1.67 \\
United States & 644.6 & 952.0 & 0.48 \\
Japan & 449.4 & 724.8 & 0.61 \\
South Korea & 154.9 & 473.5 & 2.06 \\
Singapore & 117.5 & 279.0 & 1.37 \\
Taiwan & 141.0 & 270.7 & 0.92 \\
Canada & 175.4 & 202.3 & 0.15 \\
India & 26.0 & 151.7 & 4.83 \\
Brazil & 31.6 & 84.2 & 1.66 \\
\hline
\end{tabular}

(Data Source: World Economic Forum (2012))

Table 4. China's Manufacturing Industry Exports in 2000 and 2011 (billion \$).

\begin{tabular}{llll}
\hline & $\mathbf{2 0 0 0}$ & $\mathbf{2 0 1 1}$ & \% change from Year 2000 to 2011 \\
\hline Manufacturing Export & 219.3 & $1,768.5$ & 7.06 \\
Total Export & 249.2 & $1,898.4$ & 6.62 \\
\& of Manufacturing Export/Total Export & 0.88 & 0.93 & \\
\hline
\end{tabular}

(Data Source: World Economic Forum (2012))

Table 5. China's Export Competitiveness, Compared with Others.

\begin{tabular}{|c|c|c|c|c|c|c|c|c|c|c|}
\hline & China & Germany & $\begin{array}{l}\text { United } \\
\text { States }\end{array}$ & Japan & $\begin{array}{l}\text { South } \\
\text { Korea }\end{array}$ & Singapore & Taiwan & Canada & India & Brazil \\
\hline $\begin{array}{l}\text { High Skill/ Technology } \\
\text { Intensity }\end{array}$ & $39 \%$ & $32 \%$ & $46 \%$ & $31 \%$ & $41 \%$ & $72 \%$ & $61 \%$ & $33 \%$ & $31 \%$ & $27 \%$ \\
\hline $\begin{array}{l}\text { Medium Skill/Technology } \\
\text { Intensity }\end{array}$ & $22 \%$ & $50 \%$ & $40 \%$ & $52 \%$ & $33 \%$ & $20 \%$ & $19 \%$ & $48 \%$ & $21 \%$ & $40 \%$ \\
\hline $\begin{array}{l}\text { Low Skill/Technology } \\
\text { intensity; Labor- } \\
\text { intensive/Resource-based }\end{array}$ & $39 \%$ & $18 \%$ & $14 \%$ & $17 \%$ & $26 \%$ & $8 \%$ & $20 \%$ & $19 \%$ & $48 \%$ & $33 \%$ \\
\hline
\end{tabular}

(Data Source: World Economic Forum (2012)) 


\section{R\&D EXPENDITURE IN CHINA}

China has almost tripled the share of GDP devoted to R\&D over the past 20 years, although it still remains below that of the U.S.

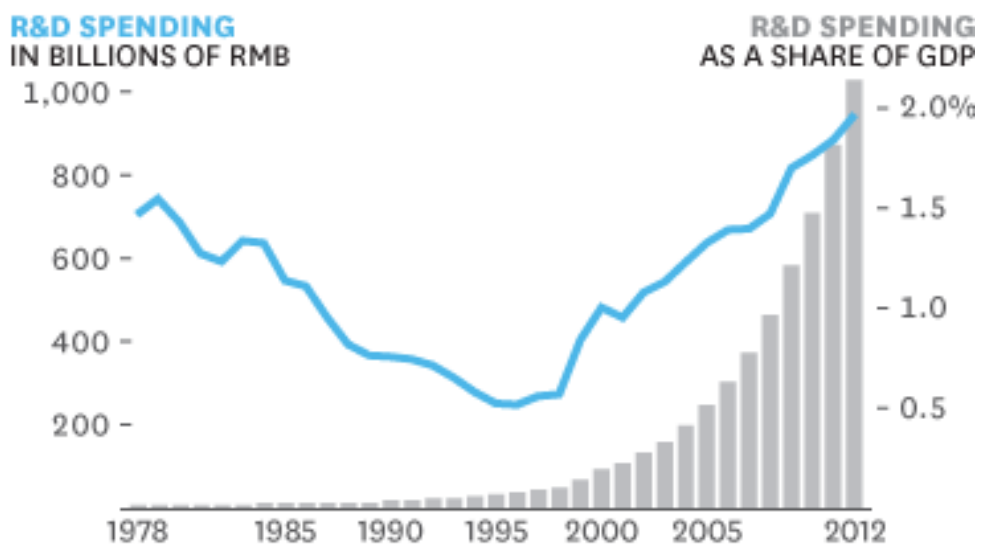

SOURCE CHINA NATIONAL BUREAU OF STATISTICS

HBR.ORG

Graph 3. China's $R$ \& D Spending Over Years (1978-2012).

\section{HOW MUCH PRODUCTIVITY IS NEEDED TO DRIVE \\ FUTURE GROWTH?}

Our research suggests that if China wants to lower the investment ratio to below $40 \%$ of GDP by the end of next decade while keeping the rate of economic growth at $10.5 \%$ (the same as in the last decade), productivity growth would need to jump from $3.3 \%$ to as much as $5.6 \%$.

\section{REQUIRED PRODUCTIVITY ANNUAL GROWTH RATE}

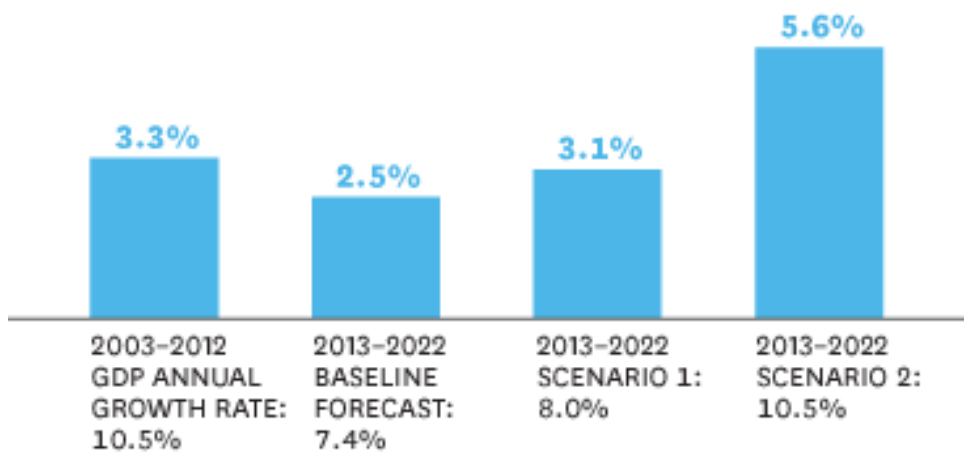

SOURCE OXFORD ECONOMICS, ACCENTURE ANALYSIS

HBR.ORG

Graph 4. China's Future Productivity Needed to Support its Economic Growth.

Table 6. China's Agriculture, Industry and Services Outputs (1990-2012)(100 million RMB).

\begin{tabular}{lllllll}
\hline & $\mathbf{1 9 9 0}$ & $\mathbf{2 0 0 0}$ & $\mathbf{2 0 0 6}$ & $\mathbf{2 0 1 0}$ & $\mathbf{2 0 1 1}$ \\
\hline Agriculture & 4954.30 & 13873.60 & 21522.30 & 36941.10 & 41988.60 & 52373.63 \\
Industry & 7717.40 & 45555.90 & 103162.00 & 185334.90 & 218217.60 \\
Service & 5996.10 & 39785.10 & 91630.10 & 179236.80 & 212675.40 \\
Total GDP & 18667.80 & 99214.60 & 216314.40 & 401512.80 & 231934.48 & 472881.60 \\
\hline
\end{tabular}

Table 7. Comparison of Employment in Agriculture, Industry and Services of China with Other Countries (2003 \& 2008).

\begin{tabular}{|c|c|c|c|c|c|c|}
\hline & \multicolumn{2}{|c|}{ Agriculture } & \multicolumn{2}{|l|}{ Industry } & \multicolumn{2}{|c|}{ Service } \\
\hline & 2003 & 2008 & 2003 & 2008 & 2003 & 2008 \\
\hline China & 49.1 & 39.6 & 21.6 & 27.2 & 29.3 & 33.2 \\
\hline Vietnam & 59.7 & 48 & 16.4 & 21 & 24 & 29.5 \\
\hline India & 59 & 51 & 16 & 19 & 22.5 & 24.4 \\
\hline Indonesia & 46.4 & 40.3 & 17.7 & 18.8 & 35.9 & 40.8 \\
\hline
\end{tabular}




\begin{tabular}{lllllll}
\hline & Agriculture & & Industry & & Service \\
\hline & $\mathbf{2 0 0 3}$ & $\mathbf{2 0 0 8}$ & $\mathbf{2 0 0 3}$ & $\mathbf{2 0 0 8}$ & $\mathbf{2 0 0 3}$ & $\mathbf{2 0 0 8}$ \\
\hline Brazil & 20.7 & 17.4 & 20.9 & 22.6 & 58.2 & 59.7 \\
Mexico & 16.8 & 13.1 & 24.8 & 25.5 & 58.4 & 60.6 \\
Russia & 10.9 & 8.6 & 30.4 & 28.9 & 58.7 & 62.4 \\
South Korea & 8.8 & 7.2 & 27.6 & 25 & 63.6 & 67.9 \\
Japan & 4.6 & 3.8 & 29.3 & 26.9 & 65.1 & 67.8 \\
Canada & 2.8 & 2.4 & 22.2 & 21.5 & 75 & 76.5 \\
German & 2.4 & 1.8 & 31.4 & 29.2 & 66.2 & 69 \\
USA & 1.7 & 1.5 & 23.2 & 19.9 & 77.5 & 78.6 \\
British & 1.3 & 1.1 & 20.9 & 21.9 & 75.4 & 76.6 \\
\hline
\end{tabular}

(Data sources: World Bank, various years reports)

Table 8. China's Urbanization Rates (1990-2012).

\begin{tabular}{llllll}
\hline Year & Total & City & \% & Countryside & \% \\
\hline 1990 & 114333 & 30195 & 26.41 & 84138 & 73.59 \\
1991 & 115823 & 31203 & 26.94 & 84620 & 73.06 \\
1992 & 117171 & 32175 & 27.46 & 84996 & 72.54 \\
1993 & 118517 & 33173 & 27.99 & 85344 & 72.01 \\
1994 & 119850 & 34169 & 28.51 & 85681 & 71.49 \\
1995 & 121121 & 35174 & 29.04 & 85947 & 70.96 \\
1996 & 122389 & 37304 & 30.48 & 85085 & 69.52 \\
1997 & 123626 & 39449 & 31.91 & 84177 & 68.09 \\
1998 & 124716 & 41608 & 33.35 & 83153 & 66.65 \\
1999 & 125786 & 43748 & 34.78 & 82038 & 65.22 \\
2000 & 126743 & 45906 & 36.22 & 80837 & 63.78 \\
2001 & 127627 & 48064 & 37.66 & 79563 & 62.34 \\
2002 & 128453 & 50212 & 39.09 & 78241 & 60.91 \\
2003 & 129227 & 52376 & 40.53 & 76851 & 59.47 \\
2004 & 129988 & 54283 & 41.76 & 75705 & 58.24 \\
2005 & 130756 & 56212 & 42.99 & 74544 & 57.01 \\
2006 & 131448 & 57706 & 43.90 & 73742 & 56.10 \\
2007 & 132129 & 59379 & 44.49 & 72750 & 5.51 \\
2008 & 132802 & 60667 & 45.68 & 72135 & 54.32 \\
2009 & 133474 & 62186 & 46.59 & 71288 & 53.41 \\
2010 & 134091 & 66978 & 49.95 & 67113 & 50.05 \\
2011 & 134735 & 69079 & 51.27 & 65656 & 48.73 \\
2012 & 135404 & 71182 & 52.57 & 64222 & 47.43 \\
\hline
\end{tabular}

chart by amCharts.com

China's Urban/Rural Population Breakdown

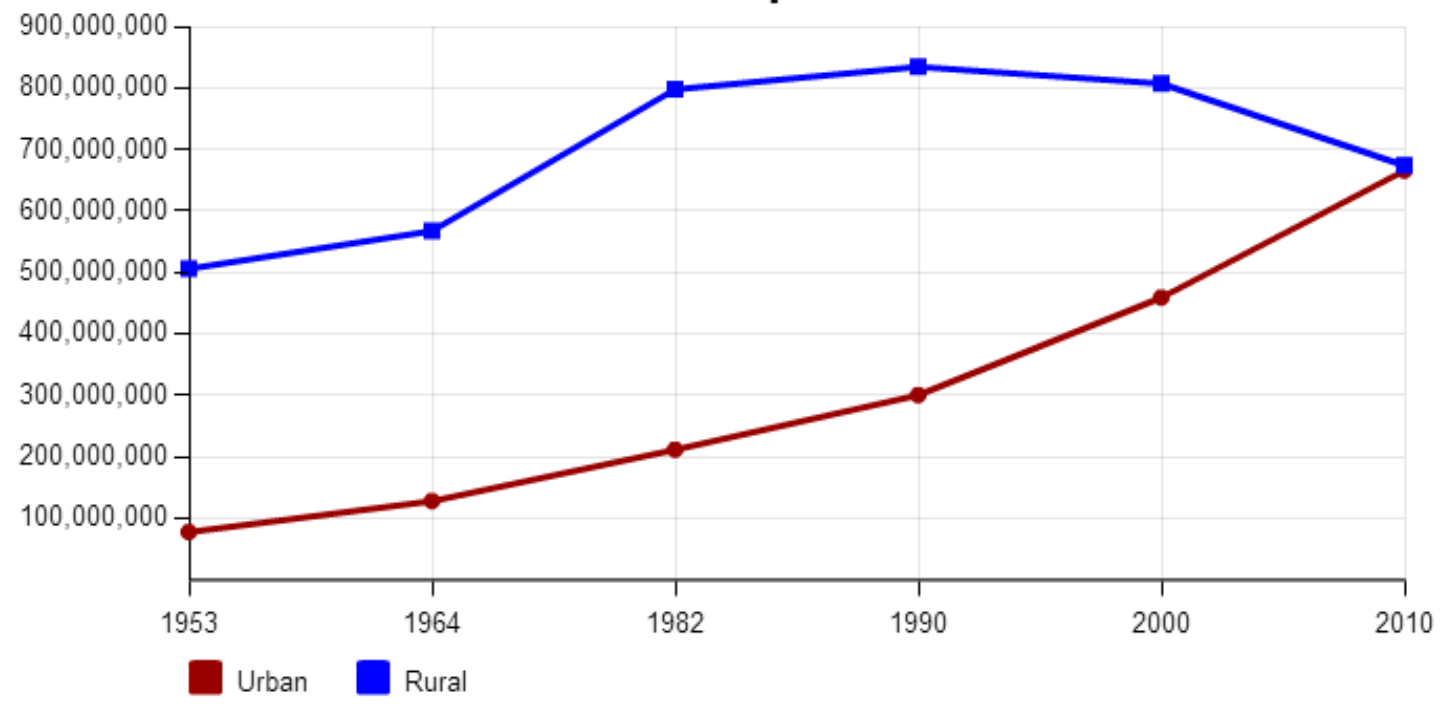

Source: National Pooulation and Family Planning Commission of PRC

Graph 5. China's Urban and Rural Population( Unit: 10,000) (1990-2012). 


\section{Acknowledgement}

The author wants to thank University of the West for providing financial assistance to this research project (through the UWest Faculty Research Grant) and also wants to thank UWest students Lina Chen, Kathleen $\mathrm{Wu}$ and Amelie Jiang for their fine research assistance. This paper was presented at the $24^{\text {th }}$ International Conference on the Pacific Rim Management, July 10-12 ${ }^{\text {th }}, 2014$, Los Angeles; the author thanks the participants for valuable comments.

\section{References}

[1] Acemoglu, D, Johnson, S, Robinson, JA, and Aghion, P. (2005), "Institutions as a Fundamental Cause of Long-run Growth," Handbook of Economic Growth, Vol. 1A, 22: 385472. ELSEVIER SCIENCE BV.

[2] Ahlstrom, D., Bruton, G., and Yeh, K. (2007), "Venture Capital in China: Past, Present, and Future", Asia Pacific Journal of Management, Vol. 24, No.3, pp.247-268.

[3] Allen, Franklin, Qian, Meijun, and Qian, Jun. (2008), China's Financial System: Past, Present, and Future, in China's Great Economic Transformation, New York, Cambridge: Cambridge University Press.

[4] Barro, Robert (1997), Determinants of Economic Growth. Cambridge, MA: MIT Press Blumstein C, Kreig B, Schipper L, and York C. (1980), "Overcoming Social and Institutional Barriers to Energy Efficiency,” Energy 5: 355-72.

[5] Bloom, Nicholas, Paul M. Romer, Stephen J. Terry, and John Van Reenen (2013), "A Trapped-Factors Model of Innovation." American Economic Review, 103(3): 208-13

[6] Bohi D, Toman M. (1996), Economics of Energy Security. Norwell, MA: Kluwer Academic Publishers.

[7] Buckley, P., Clegg, L., Cross, A., Liu, X., Voss, and H., Zheng, P. (2007), "The Determinants of Chinese Outward Foreign Direct Investment", Journal of International Business Studies, Vol. 38 pp.499-518.

[8] Brandt, Loren, and Rawski, Thomas G. (2008), China's Great Economic Transformation, in China's Great Economic Transformation, Cambridge: Cambridge University Press.

[9] Chan, K.W.(2007), "Fundamentals of China's Urbanization and Policy," University of Washington; Working paper.

[10] Chang, G.H.(2002), “ Test of the Urbanization Lag of China and its Cost in Employment," Working Paper, Department of Economics, The University of Toledo.

[11] Chang, G.H., and Brada, J.C.(2006), "The Paradox of China's Growing Under-urbanization," Economic System, 30(1), 2440.

[12] Chen, Yueyun (2011), "Why There are Less China-madeProducts in US Supermarkets?" Yazhou Zhoukan (HK Asian Weekly), June $11^{\text {th }}$.

[13] Coase, Ronald (1937),'The Nature of the Firm," Economica 4(4): 386-405.
[14] Levine, Ross (1999), "Law, Finance, and Economic Growth," Journal of Financial Intermediation, 8(1/2): 36-67.

[15] Lardy, Nicholas and Branstetter, Lee (2008), China's embrace of globalization; in China's great economic transformation, New York, Cambridge: Cambridge University Press.

[16] Cai, Fang (2010), "Labor Market Development and Expansion of Rural and Urban Employment." In Transforming the Chinese Economy, edited by Fang Cai, 85-114. Leiden and Boston: Brill.

[17] Chow, G. C. (2002), China's Economic Transformation, Wiley Publishing.

[18] Chow, G. C. (2006), "Globalization and China's Economic Development," Pacific Economic Review, 11: 271-285.

[19] Contractor, F.J. (2012), "7 reasons to Expect US Manufacturing Resurgence", Yale Global, August.

[20] Duysters, G., Jacob, J., Lemmens, C., and Yu, J. (2009), "Internationalization and Technological Catching up of Emerging Multinationals: a Comparative Case Study of China's Haier Group", Industrial and Corporate Change, Vol. 18 No.2, pp.325-349.

[21] Fuller, Brandon and Romer, Paul (2014), "Urbanization as Opportunity," Working Paper; Marron Institute: On Cities and the Urban Environment, New York University.

[22] Gallagher, Kevin and Robert Porzecanski (2008), "Climbing up the Technology Ladder? High-Technology Exports in China and Latin America," Center for Latin America Studies, UC Berkeley, Working paper, No. 20.

[23] Golove W, Eto J. (1996), Market Barriers to Energy Efficiency: A Critical Reappraisal of the Rationale for Public Policies to Promote Energy Efficiency. Lawrence Berkeley National Laboratory, LBL-38059, UC-1322, Berkeley, CA.

[24] Howarth R, and Andersson B. (1993),"Market Barriers to Energy Efficiency," Energy Economics 15:262-72.

[25] Huang, Yasheng (2010), "Debating China's Economic Growth: The Beijing Consensus or the Washington Consensus," Academy of Management Perspective, pp31-48.

[26] Lardy, N. (1998), China's Unfinished Economic Revolution, Brookings Institution Press, Washington, DC.

[27] Li, Lanqing (2009); Breaking Through: The Birth of China's Opening-Up Policy. Oxford and New York: Oxford University Press.

[28] Lin, Justin Yifu, Cai, Fang and Li, Zhou (2003); The China Miracle: Development Strategy and Economic Reform; Hong Kong: Chinese University Press.

[29] Lin, Justin Yifu(2012), The Quest for Prosperity: How Developing Countries Can Take Off, Princeton: Princeton University Press.

[30] Lin, Justin Yifu( 2012), New Structural Economics: A Framework for Rethinking Development Policy, Washington, World Bank.

[31] Demystifying the Chinese Economy, Cambridge University Press, 2012, English edition Li, S.M.(2005), "China's Changing Urban Space: Review and Synthesis," Issues and Studies, 41(4), 67-106. 
[32] Logan, J.R.(Ed.) (2002). The new Chinese City: Globalization and Market Reform. Oxford, UK: Blackwell Publishers.

[33] Lucas, Robert (1990), "Why doesn't Capital Flow from Rich to Poor Countries?" American Economic Review 80 (2): 92-96.

[34] Metcalf GE. (1994), " Economics and Rational Conservation Policy,” Energy Policy 22: 819-25

[35] Mark Purdy (2013), "China's Economy in Six Charts" Harvard Business Review, November 29.

[36] Ricardo, David(1817), On the Principles of Political Economy and Taxation (1 ed.), London. McKinsey Global Institute (2012), "Manufacturing the Future: The Next Era of Global Growth and Innovation," McKinsey \& Company. National Bureau of Statistics of China, various years.

[37] North, Douglass (1990), Institutions, Institutional Change and Economic Performance. Cambridge: Cambridge University Press.

[38] Perkins, Dwight $\mathrm{H}$ and Rawski, Thomas G (2008), "Forecasting China's Economic Growth to 2025," The China Business Review 35.6 : 34-39,45.

[39] Putterman, L.(1996), “ The Role of Ownership and Property Rights in China's Economic Transition," In A.G. Walder(Ed.), China's Transitional Economy (pp. 85-102).Oxford: Oxford University Press.

[40] Ramo, J C. (2004), Beijing Consensus, Foreign Policy Centre, London.

[41] Romer, David (2011). "The Solow Growth Model". Advanced Macroeconomics (Fourth ed.). New York: McGraw-Hill. pp. 6-48.

[42] Romer, Paul (2010), "Which Parts of Globalization Matter for Catch-Up Growth?" American Economic Review, Vol. 100, No. 2, 94-98

[43] Romer, Paul (1996), "Why, Indeed, in America? Theory, History, and the Origins of Modern Economic Growth," American Economic Review, Vol. 86. No. 2, 202-206.

[44] Romer, Paul (1989), "Capital Accumulation in the Theory of Long Run Growth," Modern Business Cycle Theory, Robert J. Barro (ed.), Cambridge: Harvard University Press.

[45] Romer, Paul (1994), "The Origins of Endogenous Growth," Journal of Economic Perspectives 8, 3-22.

[46] Romer, Paul (1991), "International Trade with Endogenous Technological Change" (joint with Luis Rivera-Batiz), European Economic Review 35(4), 971-1004.

[47] Romer, Paul (1990), "Endogenous Technological Change," Journal of Political Economy 98, S71-S102.

[48] Sit, V.F.S., and Yang,C.(1997), "Foreign-investment-induced Exo-urbanization in the Pearl River Delta, China," Urban Studies, 34(4), 647-677.
[49] Sutherland R. J. (1996), "The Economics of Energy Conservation Policy," Energy Policy 24: 361-70.

[50] Solow, Robert M. (1956), "A Contribution to the Theory of Economic Growth". Quarterly Journal of Economics 70 (1): $65-94$.

[51] Solow, Robert M. (1957), "Technical Change and the Aggregate Production Function". Review of Economics and Statistics 39 (3): 312-320.

[52] Swan, Trevor W. (1956), "Economic Growth and Capital Accumulation". Economic Record 32 (2): 334-361.

[53] Tyers, Rod and Jane Golley (2010), "China's Growth to 2030: The Roles of Demographic Change and Financial Reform", Review of Development Economics, 14 (3), 592-610.

[54] Xu, Chenggang (2011), "The Fundamental Institutions of China's Reforms and Development," Journal of Economic Literature 49.4 : 1076-1151.

[55] Zhu, Xiaodong (2012); "Understanding China's Growth: Past, Present, and Future," The Journal of Economic Perspectives $26.4: 103-124$.

[56] Contractor, Farok (2013), "Punching above their weigh: The sources of competitive advantage for emerging market multinationals," Int'Journal of Emerging Markets; Vo. 8, No. 4.pp 304-328.

[57] UNCTAD (2012), World Investment Report 2012, United Nations, Geneva,

[58] Walton H. Hamilton (1919), "The Institutional Approach to Economic Theory," American Economic Review, 9(1), Supplement, pp. 309-318.

[59] Wei, D.Y., \& Leung, C.K.(2005). "Development zones, foreign investment, and global city formation in Shanghai," Growth and Change, 36(1), 16-40.

[60] Williamson, Oliver. 1975. Markets and Hierarchies: Analysis and Antitrust Implications. The Free Press, New York.

[61] World Economic Forum (2012), “ The Future of Manufacturing Report: Manufacturing for Growth Strategies for Driving Growth and Employment," World Economic Forum.

[62] Zhang, K.H.(2002), "What Explains China's Rising Urbanization in the Reform Era?" Urban Studies, 39(12), 2301-2315.

[63] Zhao, S.X.B., Chan, R.C.K., and Sit, K.T.O.(2003), Globalization and the Dominance of Large Cities in Contemporary China. Cities, 20(4), 265-278.

[64] Zhao, S.X.B., and Zhang, L.(2007), "The Foreign Direct Investment and the Formation of Global City-regions in China. Regional Studies, 41(7), 979-994. 